\title{
L-THREONINE DEHYDROGENASE OF ESCHERICHIA COII K-12
}

Sharon A. Boylan and Eugene E. Dekker

The Department of Biological Chemistry, The University of Michigan

\author{
Ann Arbor, Michigan 48109
}

Received September 2,1978

Summary -- A rapid method for purifying I-threonine dehydrogenase from Escherichia coli $\mathrm{K}-12$ cells, grown on a medium containing L-threonine as carbon source, has been developed. The procedure consists of three fractionation steps of which the last is adsorption and elution of the enzyme from a column of Blue dextran-Sepharose. Homogeneous and stable samples of the dehydrogenase are obtained. I-Threonine dehydrogenase of $\mathrm{E}$. coli has an average molecular weight of 140,000 and consists of 4 identical or nearly identical subunits. $\mathrm{K}_{\mathrm{m}}$ values for $\mathrm{L}$-threonine and $\mathrm{NAD}^{\oplus}$ are $1.4 \mathrm{mM}$ and $0.19 \mathrm{mM}$, respectively; several substrate and coenzyme analogs are also active. The pH optimum is 10.3 and $\mathrm{Mn}^{++}$stimulates dehydrogenase activity. Other properties of the pure enzyme have been established.

\section{INTRODUCTION}

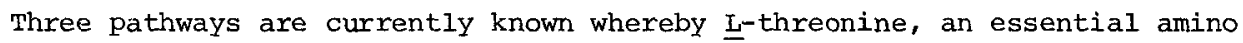
acid for mammals, is catabolized. In one, the cleavage of threonine into acetaldehyde plus glycine, as catalyzed by threonine aldolase, is the first reaction. Threonine dehydratase initiates another route wherein threonine is converted to ammonia and 2-ketobutyrate; the latter compound, in turn, is metabolized to propionyl COA. The third pathway, in which threonine dehydrogenase is the first enzyme, has received considerably less attention but appear to be assuming a position of greater importance in the metabolism of threonine by both eucaryotes and procaryotes. Of the three enzymes that initiate these separate routes for threonine degradation, only threonine dehydrogenase has resisted extensive purification; the properties of the pure enzyme have not been reported so far and numerous facets of the complete pathway in which it catalyzes the first step $\left[\right.$ L-threonine $+\mathrm{NAD}^{\oplus} \rightarrow(\alpha$-amino- $\beta$-ketobutyrate $) \rightarrow$ aminoacetone $\left.+\mathrm{CO}_{2}+\mathrm{NADH}\right]$ have not been delineated. Elliott (1) first observed that aminoacetone accumulated as a product when washed cells of 
Staphylococcus aureus (grown aerobically) were suspended in a minimal salts medium containing threonine as carbon and nitrogen source. Subsequently, cell-free extracts of E. Coli [type 1] (2) and Rhodopseudomonas spheroides as well as homogenates of liver [guinea pig (4), rat (5), and bull frog (6)] and of other rat tissues [kianey, heart, and brain] (5) were found to cataIyze an $N A D^{\oplus}$-dependent conversion of threonine to aminoacetone. It was postulated that the expected product of threonine oxidation, i.e. $\alpha$-amino- $\beta$ ketobutyrate, must spontaneously decarboxylate at physiological pH values to form the aminoketone. In later studies with soil bacteria grown on threonine as sole carbon and nitrogen source, McGilvary and Morris (7) reported the presence of a ligase that could catalyze the reversible cleavage of $\alpha$-aminoB-ketobutyrate with release of glycine plus acetyl-CoA.

Significant purification of threonine dehydrogenase has not been achieved in all studies so far reported. The most active preparations were obtained by McGilvary and Morris (8) from extracts of an Arthrobacter species isolated from soil. Their final preparations (38.5-fold purified) had a specific activity of 6.05 and were highly unstable, losing all activity overnight in phosphate buffers or having a "half-life" of about 1 week at $-15^{\circ} \mathrm{C}$ in Tris $\mathrm{HCl}$ buffer ( $\mathrm{pH}$ 8.0). We report here our ability to obtain, by a simple and rapid procedure, homogeneous samples of L-threonine dehydrogenase from Escherichia coli $\mathrm{K}-12$ that are very stable and orders of magnitude more active than any previously reported.

\section{MATERIALS AND METHODS}

Substrates, Coenzymes, and Analogs -- The following compounds were obtained from the sources indicated: L-threonine, D-threonine, DL-threonine hydroxamate, DL-threonine methyl ester $\cdot \mathrm{HCl}$, threo-DL- $\beta$ - phenylserine (Sigma Chemical Co.); $\overline{\mathrm{DL}}-$ allothreonine and $\beta$-hydroxybutyrate (Nutritional Biochemicals Corp.); L-serine, DL- $\alpha$-amino-n-butyric acid, DL- $\alpha$-amino- $\beta$-hydroxyvaleric acid (Calbiochem); L-threonine amide $\cdot \mathrm{HCl}$ (Vega Fox Biochemicals); $\mathrm{NAD}^{\oplus}$, NADP ${ }^{\oplus}, 3-a c e t y$ lpyridine- $^{-}$ $\vec{N} A D^{\oplus}$, deamino-NAD ${ }^{\oplus}$, 3-pyridine aldehyde-NAD ${ }^{\oplus}$, and thionicotinamide-NAD ${ }^{\oplus}$ (P-L Biochemicals). L-allothreonine was a gift from B. Beyer (The University of Michigan).

Measurement of L-Threonine Dehydrogenase Activity -- One of the following two assays was routinely used. In a colorimetric assay, the amount of aminoacetone formed after a fixed reaction time was measured by the procedure of 
Mauzerall and Granick (9), as modified by Gibson et al. (10). Mixtures (1.4 ml volume) containing 200 umoles of Tris.HCl buffer (pH 8.4), 125 umoles of L-threonine, and enzyme sample were subjected to a prior incubation at $37^{\circ} \mathrm{C}$

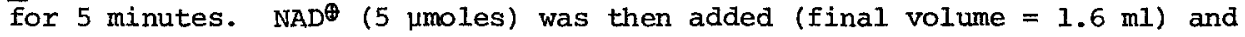
incubation at $37^{\circ} \mathrm{C}$ continued for an additional 30 minutes. After $0.4 \mathrm{mI}$ of $25 \%$ $(w / v)$ trichloroacetic acid solution was added to stop the reaction, aminoacetone was determined in $1.0 \mathrm{ml}$ aliquots of the deproteinized supernatant fluids. This procedure was most frequently used with crude preparations of threonine dehydrogenase. One unit of enzyme activity is defined as the amount that catalyzes the formation of $1.0 \mu$ mole of aminoacetone per minute. Specific activity is expressed as units per milligram of protein.

The second assay, more rapid and also suitable for kinetic studies, consisted of following NADH formation at $340 \mathrm{~nm}$; measurements were made with the use of a Gilford Model 2000 spectrophotometer equipped with a thermostatted multicuvette changer, a digital absorbance meter, and a Honeywell recorder.

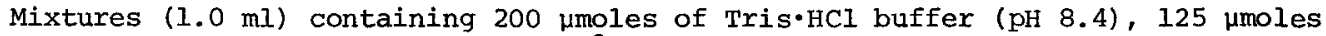
of $\mathrm{L}$-threonine, and 5 moles of $N A D^{\oplus}$ were first incubated for 5 minutes at $37^{\circ} \mathrm{C}$. The reaction was initiated by adding enzyme $(10-20 \mu 1)$; the temperature was maintained at $37^{\circ} \mathrm{C}$. Linear reaction rates were obtained for the first $1-2$ minutes. In this instance, one unit of enzyme activity is defined as the amount that catalyzes the formation of 1.0 mole of NADH per minute. A molar extinction coefficient of $6.22 \times 10^{3}$ was used for NADH. Control mixtures, lacking either enzyme, or $\mathrm{L}$-threonine, or $\mathrm{NAD}^{\oplus}$, were routinely included in both assay procedures.

Media for Growing Escherichia coli -- To isolate the strain of E. coli K-12 used in these studies, cells were forced to grow in Vogel-Bonner medium (11) containing $0.2 \%$ L-threonine as sole carbon source. Large quantities of cells required for purification of threonine dehydrogenase were obtained by growing the isolated $\mathrm{E}$. coli culture in a Fermacell fermentor containing modified Fraser and Jerrel's medium (12) with this composition: $0.84 \% \mathrm{Na}_{2} \mathrm{HPO}_{4}, 0.45 \%$ $\mathrm{KH}_{2} \mathrm{PO}_{4}, 0.15 \% \mathrm{NH}_{4} \mathrm{Cl}, 0.03 \% \mathrm{MgSO}_{4} \cdot 7 \mathrm{H}_{2} \mathrm{O}, 0.8 \%$ glycerol, and $0.25 \%$ casein hydrolysate.

RESULTS AND DISCUSSION

Preparation and Purity of I-Threonine Dehydrogenase -- Extracts of the

E. coli mutant we obtained by forcing the microorganism to grow on L-threonine as sole carbon source have levels of threonine dehydrogenase approximately 20 times higher than E. coli k-12 grown on a minimal salts + glycerol medium; conversely, threonine dehydratase and aldolase levels in extracts of the mutant are lower than threonine dehydrogenase by factors of 4 and 90 , respectively. The level of dehydrogenase activity does not decrease significantly when these cells are grown either (a) for several generations in a Vogel-Bonner medium containing $0.25 \%$ glucose or (b) in a Fermacell fermentor on modified Fraser and Jerrel's medium.

The dehydrogenase is purified approximately 80 -fold by the procedures outlined in Table I (starting with $100 \mathrm{gm}$, wet weight, of cells). All purifica- 
TABLE I

PURIFICATION OF E. COLI L-THREONINE DEHYDROGENASE

\begin{tabular}{cccc}
\hline Fraction* & Protein & $\begin{array}{c}\text { Specific } \\
\text { Activity }\end{array}$ & $\begin{array}{c}\text { Total } \\
\text { Units }\end{array}$ \\
\hline I. Crude extract & $\mathrm{mg} / \mathrm{ml}$ & units/mg & $1.6 \times 10^{3}$ \\
II. Heated to $60^{\circ} \mathrm{C}$ & 7.9 & 0.42 & $1.5 \times 10^{3}$ \\
III. DEAE-Sephadex eluate & 1.8 & 0.74 & $5.3 \times 10^{2}$ \\
IV. Blue dextran- & 0.5 & 2.3 & $1.9 \times 10^{2}$ \\
\hline
\end{tabular}

* Fractions were uniformly tested for dehydrogenase activity by the colorimetric assay for aminoacetone.

tion steps are carried out at $4^{\circ} \mathrm{C}$ unless otherwise noted. Activity is eluted from the DEAE-Sephadex column (Step III) with a gradient $(0.1 \underline{M} \rightarrow 0.4 \underline{M}$ ) of $\mathrm{KCI}$ solution. The most effective step is the adsorption of the enzyme by a column of Blue dextran-Sepharose (Step IV), prepared by a modification of the procedure of Ryan and Vestling (13). After the column is washed extensively, a pulse of $N A D^{\oplus}$ elutes the enzyme in homogeneous form (FIG. 1). The final preparation is dialyzed against $0.05 \mathrm{M}$ Tris. $\mathrm{HCl}$ buffer ( $\mathrm{pH}$ 8.4) containing $1 \mathrm{mM}$ 2-mercaptoethanol and then reduced in volume until the protein concentration is about $0.5 \mathrm{mg} / \mathrm{ml}$. When stored in this condition at $4^{\circ} \mathrm{C}$, we have found the enzyme retains full activity over a period of 2 months. The specific activity of homogeneous enzyme samples is around 34-35.

Electrophoresis of Fraction IV (70-80 $\mathrm{\mu g}$ of protein) on polyacrylamide gels at pH 9.0 and $7.0(14,15)$ shows a single protein-stainable band which is coincident with dehydrogenase activity. Homogeneity of the enzyme is also indicated by sedimentation equilibrium and sedimentation velocity ultracentrifugal procedures; FIG. 2 shows that only one sharp schlieren peak is observed throughout a typical sedimentation velocity run. Other methods used to determine the molecular weight and subunit structure of the enzyme (see the following) further substantiated the homogeneous nature of the enzyme. 


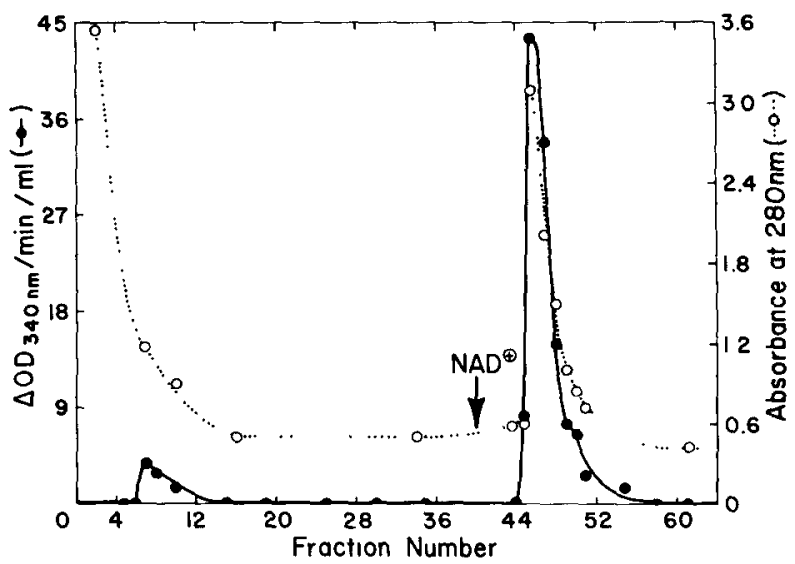

FIG. 1 Chromatography of E. coli threonine dehydrogenase on a column of Blue dextran-sepharose. The column was initially equilibrated with $10 \mathrm{mM}$ Tris $\mathrm{HCl}$ buffer ( $\mathrm{pH} 7.5$ ) containing $1 \mathrm{mM}$ 2-mercaptoethanol. Starting with Fraction No. 41, a pulse of $5 \mathrm{mM} \mathrm{NAD}^{\oplus}$ was applied; 8-ml fractions were collected.
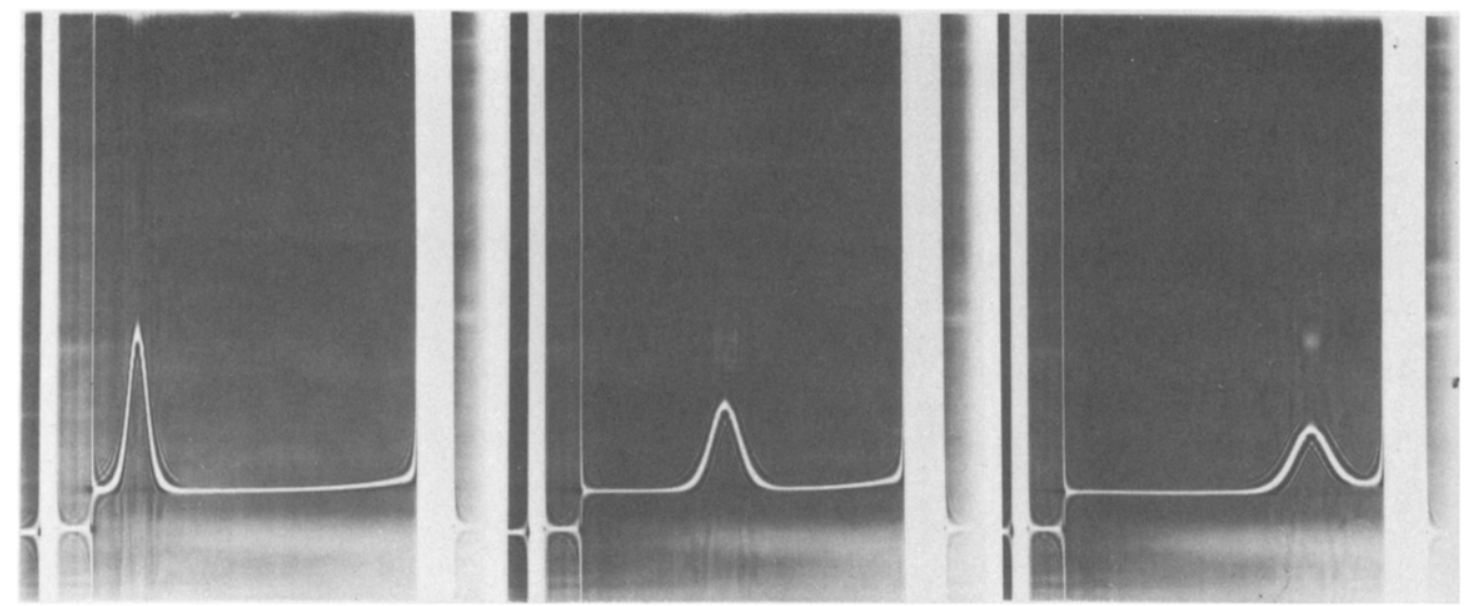

FIG. 2

Sedimentation velocity pattern of $\mathrm{E}$. coli threonine dehydrogenase after 24, 72, and 120 minutes of ultracentrifugation at 52,000 rpm. The enzyme (5.4 $\mathrm{mg}$ per $\mathrm{ml}$ ) was dialyzed against 0.02 ionic strength potassium phosphate buffer, $\mathrm{pH} 7.5$, containing $1 \mathrm{mM}$ 2-mercaptoethanol and $0.1 \mathrm{M} K \mathrm{KCl}$. Direction of sedimentation is to the right.

Molecular Weight and Subunit Composition -- Several methods were applied to establish the molecular weight of the dehydrogenase. Sucrose density gradient centrifugation, using $5-20 \%$ gradients together with suitable proteins of known size, was carried out according to the method of Maxtin and Ames (16). Values were also obtained by the use of a calibrated column of Sephadex G 200 
(17) as well as by sedimentation equilibrium centrifugation (at three different protein concentrations) in a Beckman Model E ultracentrifuge. Consistent values for a molecular weight of $140,000 \pm 5,000$ were obtained.

E. coli threonine dehydrogenase was determined to be a tetramer, consisting of 4 identical or nearly identical subunits (molecular weight $=35,000 \pm$ 1,000), by polyacrylamide gel electrophoresis in 1\% SDS (18) and by sedimentation equilibrium centrifugation in $6 \underline{M}$ guanidine $\mathrm{HCl}$. Additionally, when the enzyme is crosslinked by reaction with dimethyl suberimidate and then subjected to SDS-polyacrylamide gel electrophoresis (19), four discrete protein bands of appropriate molecular weights are seen. The tetrameric nature of the dehydrogenase was further confirmed by determining the amino acid composition, from which a minimum molecular weight of 35,400 is calculated.

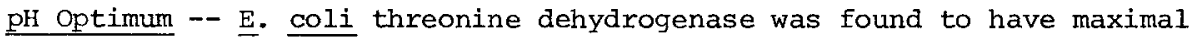
activity at $\mathrm{pH} 10.3$ (FIG. 3). The peak of the curve is quite sharp with dehydrogenase activity dropping sharply between $\mathrm{pH}$ values of 10.3 to 11.0 and 10.3 to 9.0

Other General Properties of the Enzyme -- Various kinetic studies and double reciprocal plots indicate that the reaction is sequential; the $\mathrm{K}_{\mathrm{m}}$ for I-threonine as substrate is $1.43 \mathrm{mM}$ in $50 \mathrm{mM}$ Tris $\cdot \mathrm{HCl}$ buffer $\left(\mathrm{pH} 8.4\right.$ ) and $37^{\circ} \mathrm{C}$ compared to $0.19 \mathrm{mM}$ for $\mathrm{NAD}^{\oplus}$ under identical conditions. $\mathrm{V}_{\max }=57 \mu \mathrm{moles} / \mathrm{min} /$ mg of protein. Of the three stereoisomers of I-threonine, only D-allothreonine shows any activity. Among a wide variety of substrate analogs tested, these compounds showed the relative $\mathrm{V}_{\max }$ values indicated: L-threonine (100\%), I-threonine amide (98\%), DL- $\alpha$-amino- - -hydroxyvaleric acid (71\%), DL-threonine methyl ester (27\%), DL-threonine hydroxamate (25\%), L-serine (4\%) and threo-DL$\beta$-phenylserine (3\%). Homogeneous threonine dehydrogenase from E. coli does not utilize $\beta$-hydroxybutyrate as substrate, contrary to what Neuberger and Tait (3) and Green and Elliott (5) observed with relatively impure preparations of the enzyme from Rhodopseudomonas spheroides and rat liver, respectively. Whereas $N^{A} A P^{\oplus}$ is inactive, dehydrogenase activity is observed with a number of $N_{A D}{ }^{\theta}$ 


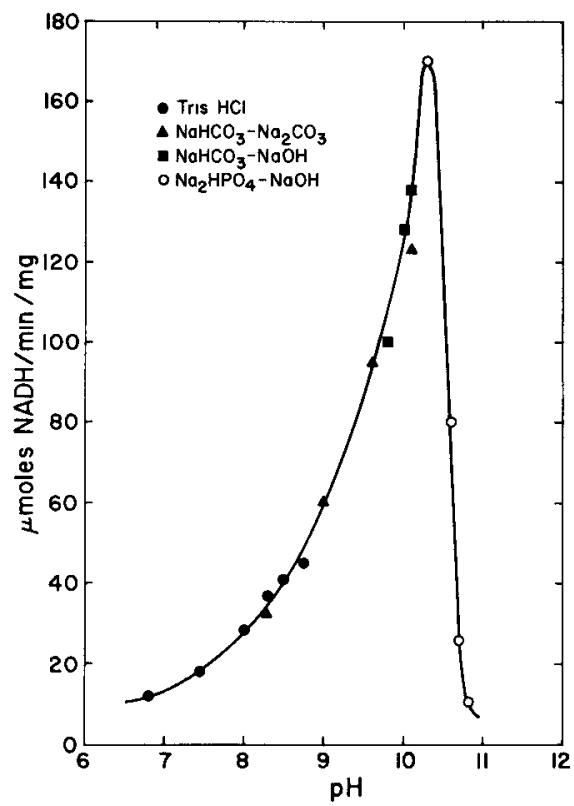

FIG. 3 Dependence of E. Coli threonine dehydrogenase activity on pH. The final concentration of all buffers used was $0.4 \mathrm{M}$. Enzymatic activity was measured by the spectrophotometric $\overline{a s s a y}$. The data obtained at all pH values are corrected for any spontaneous decomposition of $\mathrm{NAD}^{\oplus}$, which is more evident in the highly alkaline solutions.

analogs, including 3-acetylpyridine-NAD ${ }^{\oplus}$, deamino-NAD ${ }^{\oplus}, 3$ pyridine aldehyde$\mathrm{NAD}^{\oplus}$, and thionicotinamide-NAD ${ }^{\oplus}$. Exhaustive dialysis of the enzyme against $0.1 \mathrm{mM}$ EDTA causes a 30-40\% loss of activity. Both $10 \mathrm{w}\left(6.4 \times 10^{-2} \mathrm{mM}\right)$ and high $(3.2 \mathrm{mM})$ concentrations of $\mathrm{Mn}^{++}$significantly stimulate EDTA-treated enzyme. Efforts are continuing to completely elucidate the properties of this homogeneous enzyme.

As indicated earlier, L-threonine dehydrogenase occupies a key position in that it catalyzes the first step in one of three known pathways for I-threonine catabolism. Having developed a simple and rapid method for obtaining this dehydrogenase in homogeneous form, we are now in a position to carefully study its structure, function, and possible regulation. Attempts to explore the mechanism of the reaction catalyzed should also be possible now. It remains to be determined whether an "aminoacetone cycle" (1) or an alternate path 
involving an $\alpha$-amino- $\beta$-ketobutyrate ligase represents the physiologically

significant route in the catabolic pathway initiated by L-threonine dehydrogenase.

\section{ACKNOWLEDGMENTS}

This investigation was supported by Grant AM-03718 from the National Institute of Arthritis, Metabolism, and Digestive Diseases, U. S. Public Health Service. Special thanks are due to Dr. J. Lawrence Oncley and Mr. John Trojanowski for their help in carrying out the sedimentation velocity runs with the ultracentrifuge.

\section{REFERENCES}

1. Elliot, w. H. (1959) Nature 283, 1051-1052

2. Turner, J. M. (1967) Biochem. J. 204, 112-121

3. Neuberger, A., and Tait, G. H. (1962) Biochem. J. 84, 317-328

4. Urata, G., and Granick, S. (1963) J. Biol. Chem. 238, 811-820

5. Green, M. L., and Elliot, W. H. (1964) Biochem. J. 92, 537-549

6. Hartshorne, D., and Greenberg, D. M. (1964) Arch. Biochem. Biophys. 205, 173-178

7. McGilvary, D., and Morris, J. G. (1971) Methods in EnzymoLogy XVIIB, 585-589

8. McGilvary, D., and Morris, J. G. (1971) Methods in Enzymology XVIIB, 580-584

9. Mauzerall, D., and Granick, S. (1956) J. Biol. Chem. 2l9, 435-446

10. Gibson, K. D., Laver, W. G., and Neuberger, A. (1958) Biochem. J. 70, $71-81$

11. Vogel, H. J., and Bonner, D. M. (1956) J. Biol. Chem. 2Z8, 97-106

12. Fraser, D., and Jerrel, E. A. (1953) J. Biol. Chem. 205, 291-295

13. Ryan, L. D. and vestling, C. S. (1974) Arch. Biochem. Biophys. 260, 279-284

14. Davis, B. J. (1964) Ann. N. Y. Acad. Sci. Z2Z, 404-442

15. Gabriel, O. (1971) Methods in Enzymology XXII, 565-578

16. Martin, R. G., and Ames, B. N. (1961) J. Biol. Chem. 236, 1372-1379

17. Andrews, P. (1965) Biochem. J. 96, 595-606

18. Weber, K., Pringle, J. R., and Osborn, M. (1972) Methods in Enzymology XXVI, 3-27

19. Davies, G. E., and Stark, G. R. (1970) Proc. Nat2. Acad. Sci. 66, $651-656$ 